\title{
PELAYANAN PROMOTIF DAN PREVENTIF MENINGKATKAN KESEJAHTERAAN LANSIA DI DESA GAJI GUNTUR DEMAK
}

\section{PROMOTIVE AND PREVENTIVE SERVICES IMPROVING LAND WELFARE IN THE VILLAGE OF GAJI GUNTUR DEMAK}

\author{
Noveri Aisyaroh ${ }^{\# 1}$, Friska Realita ${ }^{\# 2}$, Isna Hudaya ${ }^{\# 3}$, Alfiah Rahmawati ${ }^{\# 4}$, Meilia Rahmawati ${ }^{\# 5}$ \\ \#Prodi Kebidanan, Fakultas Kedokteran, Universitas Islam Sultan Agung \\ Jl. Raya Kaligawe KM 4 Semarang, Jawa Tengah \\ 1noveri@unissula.ac.id \\ friskarealita@unissula.ac.id \\ 3isna@unissula.ac.id \\ 4alfiahrahmawati@unissula.ac.id \\ ${ }^{5}$ meilia.rahmawati@unissula.ac.id
}

\begin{abstract}
Abstrak
Populasi lansia di Indonesia semakin meningkat, supaya bisa berperan dalam pembangunan dan tidak menjadi beban Negara perlu adanya kebijakan dan program khusus bagi kelompok lansia. Timgginya UHH merupakan salah satu indikator keberhasilan pembangunan nasional di bidang kesehatan. Tujuan kegiatan pengabdian masyarakat ini adalah deteksi dini adanya masalah kesehatan lansia melalui pelayanan promotif dan preventif. Metode yang digunakan adalah pemeriksaan antropometri untuk mengetahui status gizi lansia dan pemeriksaan darah (glukosa dan asam urat) dengan sasaran para lansia di Desa Gaji, Guntur Demak. Sebagian besar usia lansia $>60$ tahun, status gizi normal, banyak yang mengalami hipertensi, terdapat $\mathbf{1 2 4 , 3 9 \%}$ glukosa dalam darah tinggi dan sebagian besar asam urat rendah. Pengkajian dan pemeriksaan yang didapatkan tidak normal dilakukan rujukan ke Puskesmas Guntur II.
\end{abstract}

Kata kunci- lansia, pemeriksaan antropometri, pemeriksaan penunjang

\section{Abstract}

The elderly population in Indonesia is increasing, so that they can play a role in development and not become a burden to the State, it is necessary to have special policies and programs for elderly groups. The timing of UHH is an indicator of the success of national development in the health sector. The purpose of this community service activity is early detection of health problems in the elderly through promotive and preventive services. The method used was anthropometric examination to determine the nutritional status of the elderly and blood tests (glucose and uric acid) targeting the elderly in Gaji Village, Guntur Demak. Most of the elderly $>60$ years, normal nutritional status, many have hypertension, there is $\mathbf{1 2 4 . 3 9 \%}$ high blood glucose and mostly low uric acid. Assessments and examinations that were found to be abnormal were referred to the Guntur II Health Center.

Keywords — elderly, anthropometric examination, investigations

\section{PENDAHULUAN}

Tingginya Usia Harapan Hidup (UHH) merupakan salah satu indikator keberhasilan pencapaian pembangunan nasional di bidang kesehatan. Adanya peningkatan UHH sejak tahun 2004 - 2015 dari 68,5 tahun menjadi 70,8 tahun dan proyekti tahun $2030-$ 2035 menjadi 72,2 tahun(1).

Proporsi penduduk lansia di Indonesia diprediksi akan terus mengalami peningkatan. Tahun 2013 jumlah kelompok lansia 8,95\%, tahun 2050 terdapat $21,4 \%$ dan tahun 2100 meningkat menjadi $41 \%$ dari total jumlah penduduk(1).

Proses penuaan akan dialami oleh semua individu, yang ditandai dari berbagai tahapan. Menurunnya berbagai sistem fungsi organ tubuh dapat menyebabkan rentan terhadap berbagai penyakit.
Dengan bertambahnya usia akan terjadi perubahan dalam struktur dan fungsi sel, jarIngan, serta sistem organ. Hal tersebut akan berpengaruh terhadap kemunduran kesehatan fisik dan psikis yang dapat berdampak pada ekonomi dan sosial lansia sehingga akan berpengaruh pada activity of daily living (Fatmah, 2010).

Penampilan suatu penyakit pada lanjut usia sering berbeda dengan pada usia muda. Disamping itu harus dibedakan, apakah kelainan yang terjadi berkenaan dengan perubahan karena bertambahnya usia, atau memang ada suatu proses patologi sebagai penyebabnya. Beberapa problematika klinik dari penyakit pada lanjut usia yang sering dijumpai (geriatric giants), meliputi; sindrom serebral, konfusio, gangguan otonom, inkontinensia, jatuh, 
kelainan tulang dan patah tulang serta decubitus. Semua problema klinik bukanlah suatu diagnosis, tetapi merupakan gejala, yang harus dicari penyebabnya.

Pada sebagian besar lansia tidak melakukan latihan olahraga secara teratur dan biasa hidup sedenter. Keadaan ini selain menurunkan fungsi organ juga meningkatkan risiko mendapatkan berbagai penyakit degenerative antara lain; hipertensi, diabetes mellitus, penyakit arteri coroner dan kecelakaan.

Mengingat berbagai kekhususan perjalanan dan penampilan penyakit pada usia lanjut, maka terdapat 2 prinsip utama yang harus dipenuhi guna melaksanakan pelayanan kesehatan pada lansia, yaitu pendekatan holistic serta tatakerja dan tatalaksana secara tim. Pelaksanaan pelayanan kesehatan usia lanjut dapat dilaksanakan di masyarakat, masyarakat berbasis rumah sakit dan berbasis rumah sakit.

Upaya kesehatan adalah setiap kegiatan untuk memelihara dan meningkatkan kesehatan yang dilakukan oleh pemerintah dan atau masyarakat. Hal ini berarti bahwa dalam rangka mewujudkan kesehatan, baik kesehatan individu, kelompok atau masyarakat harus diupayakan. Upaya mewujudkan kesehatan dilakukan oleh individu, kelompok masyarakat, baik secara kelembagaan, pemerintahan ataupun swadaya masyarakat (LSM), upaya tersebut yaitu pemeliharaan kesehatan dan peningkatan kesehatan. Pemeliharaan kesehatan mencakup 2 aspek yakni; kuratif dan rehabilitative, sedangkan peningkatan kesehatan meliputi; preventif dan promotif.

Kesehatan lansia perlu ditingkatkan karena kesehatan itu relative dan mempunyai bentangan yang luas. Oleh sebab itu, upaya kesehatan promotif mengandung makna kesehatan seseorang, kelompok atau individu harus selalu diupayakan sampai ke tingkat kesehatan yang optimal.

Posyandu lansia adalah pos layanan terpadu untuk masyarakat usia lanjut di suatu wilayah tertentu yang sudah disepakati, yang digerakkan oleh masyarakat dimana mereka bisa mendapatkan pelayanan kesehatan. Posyandu lansia merupakan pengembangan dari kebijakan pemerintah melalui pelayanan kesehatan bagi lansia yang penyelenggaraannya melalui program Puskesmas dengan melibatkan peran serta para lansia, keluarga, tokoh masyarakat dan organisasi sosial dalam penyelenggaraannya.

Desa Gaji Kecamatan Guntur Demak, merupakan desa yang terdapat posyandu lansia dengan 4 kader dan bekerjasama dengan Puskesmas Guntur II. Adanya posyandu lansia disini dapat meningkatkan jangkauan pelayanan kesehatan lansia di masyarakat, sehingga terbentuk pelayanan kesehatan yang sesuai dengan kebutuhan lansia dan dapat mendekatkan pelayanan dan meningkatkan peran serta masyarakat dan swasta dalam pelayanan kesehatan disamping meningkatkan komunikasi antara masyarakat usia lanjut.

Tujuan kegiatan pengabdian masyarakat ini adalah deteksi dini adanya masalah kesehatan lansia melalui pelayanan promotif dan preventif yaitu dengan pemeriksaan fisik maupun penunjang. Dengan adanya pelayanan tersebut dapat mendeteksi berbagai penyakit maupun masalah yang terjadi pada lansia sehingga dapat segera dilakukan rujukan ke Puskesmas Guntur II dan mendapatkan penanganan lebih lanjut.

\section{TARGET DAN LUARAN}

Target pengabdian masyarakat ini adalah publikasi artikel di jurnal pengabdian masyarakat, didapatkan hasil pemeriksaan fisik dan penunjang, perbaikan tata nilai masyarakat khususnya masyarakat lansia di bidang kesehatan dan meningkatkan kesehatan masyarakat lansia.

\section{METODE PELAKSANAAN}

Pelaksanaan pengabdian masyarakat ini dilaksanakan melalui beberapa tahap, yaitu :

1. Diskusi permasalahan kesehatan lansia di Desa Gaji dengan koordinator PKH.

2. Menentukan prioritas penyelesaian masalah kesehatan lansia.

3. Perijinan dan berkoordinasi dengan kelurahan.

4. Kerjasama dengan Puskesmas Guntur II.

Pengabdian masyarakat ini dilaksanakan di Desa Gaji, Guntur Demak dengan sasaran para lansia di RW 2, 5 dan 6 yang berada di RT $1-4$.

Kegiatan dilaksanakan bersamaan dengan posyandu lansia. Terdapat beberapa bentuk kegiatan, yaitu:

1. Anamnesis

2. Pemeriksaan antropometri, meliputi: pengukuran tinggi badan, menimbangan berat badan, pengukuran lingkar lengan atas, pengukuran lingkat perut dan lingkar betis.

3. Pemeriksaan tekanan darah.

4. Pemeriksaan penunjang, meliputi: pemeriksaan glukosa dan asam urat.

5. Edukasi kesehatan berupa konseling.

6. Pemberian makanan tambahan.

Tim pelaksana yaitu dosen peminatan Kesehatan Reproduksi Prodi Kebidanan Fakultas Kedokteran Universitas Islam Sultan Agung. Selama kegiatan, dibantu 8 mahasiswa Kebidanan semester akhir. 


\section{HASIL DAN PEMBAHASAN}

Pelaksanaan kegiatan dilaksanakan selama 2 hari yang diawali dengan koordinasi seacara langsung dengan kelurahan dan koordinator PKH. Pengabdian masyarakat dilaksanakan bersamaan dengan kegiatan posyandu lansia, total peserta yang hadir sejumlah 41 orang, sebagian besar adalah wanita dan dibantu 4 kader lansia Desa Gaji, Guntur Demak.

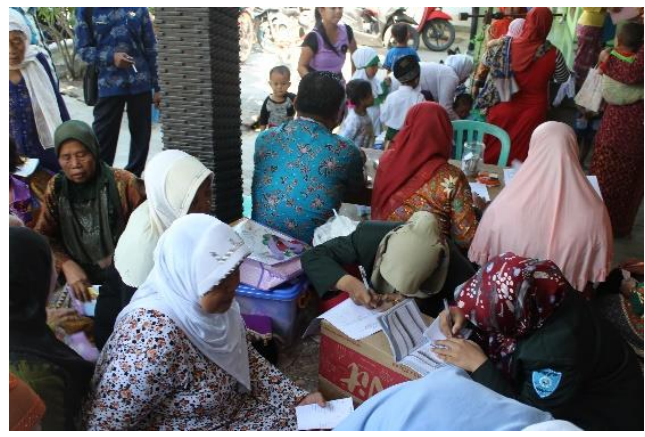

Gambar 1. Pengkajian Data Subjektif

Tabel I. Karakteristik Lansia

\begin{tabular}{ccc}
\hline Usia (tahun) & Frekuensi & $\%$ \\
\hline $45-59$ & 10 & 24,4 \\
\hline $60-74$ & 19 & 46,3 \\
\hline $75-90$ & 9 & 22 \\
\hline$>90$ & 3 & 7,3 \\
\hline Total & 41 & 100 \\
\hline
\end{tabular}

Berdasarkan tabel I sebagian besar lansia berada pada rentang usia 60 - 74 tahun sejumlah 19 orang $(46,3 \%)$. Batasan usia lanjut menurut WHO terbagi menjadi 4 bagian, yaitu: 1) usia 45 - 59 tahun disebut usia pertengahan; 2) usia 60 - 74 tahun disebut lanjut usia; 3) usia 75 - 90 tahun disebut lanjut usia tua; 4) $>90$ tahun disebut sangat tua.

Pengelompokan lansia menurut Depkes RI (2006), berbeda dengan WHO, yaitu: 1) usia 55 - 59 tahun disebut virilitas (prasenium), merupakan masa persiapan usia lanjut yang menampakkan kematangan jiwa, 2) usia 60 - 64 tahun disebut usia lanjut dini (senescen), merupakan kelompok yang mulai memasuki masa usia lanjut dini, 3) usia > 60 tahun, merupakan lansia berisiko tinggi menderita berbagai penyakit degenerative.

Semakin bertambahnya usia, fungsi biologis akan mengalami penurunan akibat dari proses degenerative (penuaan), sehingga pada lanjut usia banyak mengalami penyakit tidak menular. Pada lanjut usia juga rentan terkena infeksi penyakit menular karena menurunnya daya tahan tubuh sebagai akibat dari proses degenerative(2).

Dengan bertambahnya usia, asupan cairan perlu terjamin kecukupannya. Pusat haus dan sel-sel di ginjal menjadi kurang sensitive terhadap perubahan cairan tubuh. Lansia tidak mudah menjadi haus, dan ginjal kurang sensitive dalam mengkonsentrasikan urin sebagai respon terhadap perubahan volume cairan tubuh(3).

\begin{tabular}{ccc}
\multicolumn{3}{c}{ Tabel II. Status Gizi Lansia Berdasarkan IMT } \\
\hline IMT & Frekuensi & $\%$ \\
\hline Gizi kurang & 6 & 14,63 \\
\hline Gizi normal & 20 & 48,78 \\
\hline Obesitas & 15 & 36,59 \\
\hline Total & 41 & 100
\end{tabular}

Berdasarkan tabel II, sebagian besar status gizi lansia berdasarkan IMT adalah normal 20 orang (48,78\%). Menurut Depkes (2006), Indeks Masa Tubuh (IMT) lansia berasal dari 2 variabel antropometri pemeriksaan Tinggi Badan (TB) dan Berat Badan (BB), yang diklasifikasikan menjadi 3 status gizi, yaitu gizi kurang $(<18,5)$, gizi normal $(18,5-25)$, dan obesitas $(>25)$.

Pengamatan pada manusia menunjukkan bahwa gizi yang tidak benar, aktivitas fisik kurang, obesitas, stress, merokok dan konsumsi alkohol berlebihan berkontribusi terhadap penurunan berbagai fungsi organ di usia lanjut. Perubahan status gizi pada lansia disebabkan perubahan lingkungan maupun faali dan status kesehatan(3).

Gangguan gizi yang dapat muncul pada usia lanjut dapat berbentuk gizi kurang maupun gizi lebih. Gangguan ini dapat menyebabkan munculnya penyakit atau terjadi sebagai akibat adanya penyakit tertentu, karena gangguan gizi dapat berifat primer maupun sekunder(3).

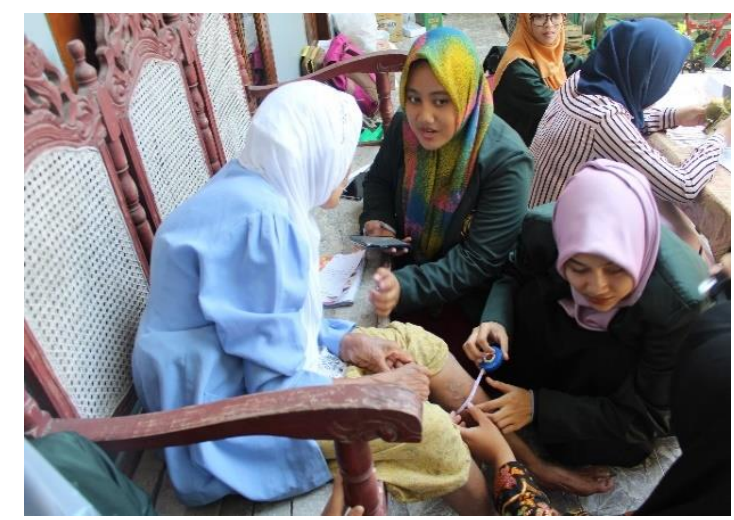

Gambar 2. Pemeriksaan Lingkar Betis

Pemeriksaan status gizi lansia dapat memberikan informasi tentang keadaan gizi saat itu dan kebutuhan nutrsi yang harus dipenuhi. Tujuan dari pengkajian status gizi untuk membuat parameter gizi secara subjektif dan objektif, mengidentifikasi kekurangan nutrisi dan menentukan faktor risiko dari masalah gizi lansia. Disamping itu juga, dapat menentukan kebutuhan gizi dan mengidentifikasi faktor psikososial dan medis yang dapat memengaruhi dukungan status gizi.

Asupan makanan sangat mempengaruhi proses menua karena seluruh aktivitas sel atau metabolisme 
dalam tubuh memerlukan zat-zat gizi yang cukup. Sementara itu perubahan biologis pada lanjut usia merupakan faktor internal yang pada akhirnya dapat memengaruhi status gizi(4).

Masalah gizi lanjut usia merupakan rangkaian proses masalah gizi sejak usia muda yang menifestasinya terjadi pada lanjut usia. Masalah gizi pada lanjut usia sebagian besar merupakan masalah gizi lebih yang merupakan faktor risiko timbulnya penyakit jantung coroner, diabetes mellitus, hipertensi, gout rematik, ginjal, dan lain-lain. Namun demikian, masalah kurang gizi juga banyak terjadi pada lanjut usia seperti Kurang Energi Kronik (KEK), anemia dan kekurangan zat gizi mikro lain.

Obesitas disebabkan karena pola konsumsi yang berlebihan, banyak mengandung lemak dan jumlah kalori yang melebihi kebutuhan. Disamping itu juga, tidak diimbangi dengan aktifitas atau penurunan jumlah makanan.

Pada prinsipnya kebutuhan gizi pada lanjut usia mengikuti prinsip gizi seimbang. Konsumsi makanan yang cukup dan seimbang bermanfaat bagi lanjut usia untuk mencegah atau mengurangi risiko penyakit degenerative dan kekurangan gizi.

\begin{tabular}{ccc}
\multicolumn{2}{c}{ Tabel III. Hasil Pemeriksaan Tekanan Darah } \\
\hline Tekanan Darah & Frekuensi & $\%$ \\
\hline Normal & 12 & 29,27 \\
\hline Hipertensi & 29 & 70,73 \\
\hline Total & 41 & 100
\end{tabular}

Berdasarkan tabel III, sebagian besar tekanan darah lansia mengalami hipertensi, yaitu 29 orang (70,73\%). Pada lansia, penyakit kardiovaskuler merupakan salah satu penyakit yang banyak ditemui. Penyakit ini, merupakan penyebab utama kematian dan disabilitas pada usia lanjut(3).

Penelitian Framingham menunjukkan bahwa pada penderita hipertensi terdapat kenaikan mortalitas total dua kali dan mortalitas kardiovaskuler tiga kali lebih tinggi dari normotensu dan hal ini lebih signifan pada wanita setelah berusia lebih dari 65 tahun.

Hipertensi, baik sistolik maupun diastolic merupakan faktor risiko dominan untuk terjadinya stroke, baik hemorrhagic maupun non hemorrhagic. Secara patologik apa yang terjadi pada pembuluh darah di otak serupa dengan apa yang terjadi di jantung, terutama jenis emboli dan thrombosis. Oleh karena itu, faktor risiko terjadinya stroke serupa dnegan fator risiko penyakit jantung iskemik(3).

Penting diketahui pada golongan usia lanjut ialah kecenderungan labilitas tekanan darah, serta mudahnya terjadi hipotensi postural. Maka dianjurkan untuk selalu mengukur tekanan darah pada posisi tidur dan tegak serta dilakukan secara rutin. Apabila hipertensi tidak dikontrol secara seksama dan teratur dengan sendirinya akan terjadi penyakit jantung hipertensif (PJH) dan komplikasi-komplikasi pada target organ yang lain, nantinya akan memberi komplikasi PJK atau gagal jantung dengan segala konsekuensinya(3).

Tabel IV. Hasil Pemeriksaan Penunjang

\begin{tabular}{cccc}
\hline \multirow{2}{*}{$\begin{array}{c}\text { Jenis } \\
\text { pemeriksaan }\end{array}$} & Kategori & Frekuensi & $\%$ \\
\hline \multirow{3}{*}{$\begin{array}{c}\text { Glukosa } \\
(\mathrm{mg} / \mathrm{dl})\end{array}$} & Rendah & 15 & 36,59 \\
\cline { 2 - 4 } & Normal & 16 & 39,02 \\
\cline { 2 - 4 } & Tinggi & 10 & 24,39 \\
\hline \multirow{2}{*}{$\begin{array}{c}\text { Asam urat } \\
(\mathrm{mg} / \mathrm{dl})\end{array}$} & Retal & 41 & 100 \\
\cline { 2 - 4 } & Normal & 29 & 70,73 \\
\cline { 2 - 4 } & Total & 41 & 29,27 \\
\hline
\end{tabular}

Berdasarkan tabel IV sebagian besar hasil pemeriksaan glukosa adalah normal $(39,02 \%)$ dan hasil pemeriksaan asam uratnya rendah $70,73 \%$. Meskipun hasil pemeriksaan glukosa sebagian besar normal, tetapi kategori rendah selisih sedikit dengan hasil pemeriksaan normal, yaitu 36,59\%. Disamping itu juga, masih banyak hasil pemeriksaan glukosa yang tinggi sebesar $24,39 \%$.

Pemeriksaan glukosa berfungsi untuk mengetahui kadar gula dalam darah. Makanan yang mengandung karbohidrat berfungsi untuk sebagai sumber energi, dimana glukosa berasal dari makanan yang mengandung karbohidrat. Kadar gula yang terlalu tinggi dapat mengganggu kesehatan lansia, seperti; merusak mata, ginjal, dan pembuluh darah. Penderita stroke seringkali merupakan penderita diabetes mellitus, sehingga kadar gula darah pasca stroke tinggi. Akan tetapi seringkali terjadi kenaikan gula darah panderita sebagai reaksi kompensasi, atau akibat mekanisme sress(3).

Asam urat rendah, jarang dikenali oleh masyarakat karena asam urat rendah biasanya tidak menimbulkan keluhan atau masalah yang signifikan. Tetapi hal tersebut sudah menunjukkan suatu kondisi yang tidak normal dan tidak dapat disepelekan karena kondisi kadar urat dalam tubuh dibawah normal. Penyebab dari asam urat rendah belum diketahui secara pasti. Beberapa kemungkinan penyebab adalah; makanan yang dikonsumsi setiap hari kurang mengandung purin (seperti; makanan laut, telur, daging, dan sayuran hijau), sering mengkonsumsi obat penurun kadar asam urat, kondisi hipertiroidisme defisiensi mineral, keracunan tembaga, dan juga karena faktor genetic.

Menua adalah suatu proses menghilangkan secara perlahan-lahan kemampuan jaringan untuk memperbaiki diri/mengganti diri dan mempertahankan struktur dan fungsi normalnya sehingga tidak dapat bertahan terhadap jejas 
(termasuk infeksi) dan memperbaiki kerusakan yang diderita. Dengan begitu, manusia secara progresif akan kehilangan daya tahan terhadap infeksi dan akan menumpuk makin banyak distorsi metabolic dan structural yang disebut sebagai "penyakit degenerative", seperti hipertensi, aterosklerosis, diabetes mellitus, dan kanker) yang akan menyebabkan menghadapi masa akhir hidup dengan episode terminal yang dramatic seperti stroke, infark miokard, koma asidotik, metastasis kanker, dan seterusnya $^{(3)}$.

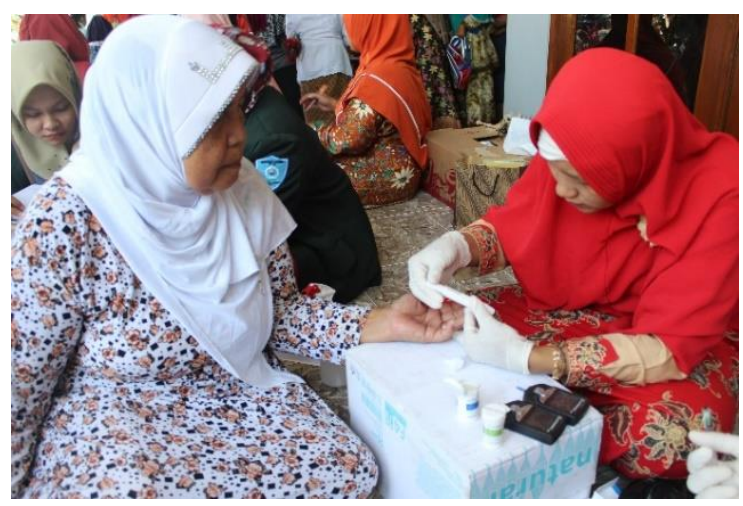

Gambar 3. Pemeriksaan Glukosa dan Uric Acid

\section{KESIMPULAN}

Kegiatan pengabdian masyarakat dalam bentuk pelayanan promotif dan preventif terlaksana dengan baik. Hasil pelayanan kesehatan didapatkan sebagian besar berada pada usia $60-74$ tahun disebut lanjut usia menurut WHO dan usia > 60 tahun menurut Depkes RI, dimana pada usia tersebut lansia berisiko tinggi menderita berbagai penyakit degenerative. Status gizi lansia berdasarkan IMT masih berada pada batas normal, tetapi banyak yang menderita hipertensi. Didapatkan 24,39\% lansia dengan glukosa yang tinggi dan $70,73 \%$ asam urat dengan hasil rendah. Hasil pemeriksaan yang mengindikasikan ke arah yang patologis dilakukan rujukan ke Puskesmas Guntur II untuk dilakukan penatalaksaan lebih lanjut.

Pelayanan kesehatan merupakan hak asasi manusia dan salah satu unsur kesejahteraan yang harus diwujudkan sesuai dengan cita-cita Bangsa Indonesia, tidak terkecuali pada lansia.

Untuk mewujudkan lanjut usia sehat berkualitas, perlu dilakukan pembinaan kesehatan sedini mungkin dan selama siklus hidup manusia sampai memasuki masa lanjut usia dengan meminimalkan faktor risiko yang harus dihindari dan memaksimalkan faktor protektif yang dapat melindungi dan meningkatkan status kesehatan.

\section{UCAPAN TERIMAKASIH}

Kegiatan pengabdian masyarakat sebagai bagian dari Tri Dharma Perguruan Tinggi ini telah terlaksana sesuai dengan kebutuhan masyarakat. Untuk itu, kami ucapkan terima kasih kepada Universitas Islam Sultan Agung Semarang.

\section{DAFTAR PUSTAKA}

[1] Kementerian Kesehatan RI. 2016. Situasi Lanjut Usia (Lansia) di Indonesia. Jakarta : Infodatin.

[2] Kementerian Kesehatan RI. 2017. Profil Kesehatan Indonesia Tahun 2016. Jakarta: Kemenkes RI.

[3] Darmojo, Boedhi dan Martono, Hadi. 2004. Geriatri (Ilmu Kesehatan Usia Lanjut). Jakarta: Fakultas Kedokteran Universitas Indonesia.

[4] Kementerian Kesehatan RI, Direktorat Jenderal Bina Gizi dan Kesehatan Ibu dan Anak. 2012. Pedoman Pelayanan Gizi Lanjut Usia. Kemenkes RI. 